\title{
Diamino Acid Transport into Granulocytes and Liver Slices of Patients with Lysinuric Protein Intolerance
}

\author{
OLLI SIMELL (39) \\ University of Helsinki Children's Hospital, Helsinki, Finland
}

\section{Extract}

The amounts of ${ }^{14} \mathrm{C}$-labeled lysine, arginine, and ornithine taken up by isolated granulocytes of 11 patients with lysinuric protein intolerance (LPI) and of 16 control subjects were measured. Transport against a concentration gradient was evident in all. The initial 5-min uptake was measured in a series of substrate concentrations varying from $0.025-4.0 \mathrm{mM}$. One transport system was seemingly present for all three amino acids. The rates of transport into the granulocytes in the patients and control subjects were comparable. The $V_{\text {max }}$, in millimoles $\times$ kilogram of cell water ${ }^{-1} \times$ $5 \mathrm{~min}^{-1}$, ranged only from $0.30-0.38$ in the patients and from $0.32-0.34$ in the control subjects. The $K_{m}$ values were 0.06 and 0.06 $\mathrm{mM}$ for lysine, 0.05 and 0.06 for arginine, and 0.10 and $0.09 \mathrm{mM}$ for ornithine in the patients and control subjects, respectively.

The transport of the nonmetabolizable diamino acid analog, homoarginine, into liver slices of three patients and five control subjects was also studied. There was no clear difference in the time course of uptake at $0.05 \mathrm{mM}$ homoarginine concentration in the medium. In kinetic studies of two patients and three control subjects, at least two transport systems were evident. The "large capacity, low affinity" system had $V_{\max }$ of 0.43 and $3.08 \mathrm{mmol} \times$ $\mathrm{kg}$ cell water ${ }^{-1} \times 15 \mathrm{~min}^{-1}$ and $K_{\mathrm{m}}$ of 0.18 and $2.49 \mathrm{mM}$ in the patients and control subjects, respectively. The "small capacity, high affinity" system had $V_{\max }$ of 0.07 and $0.14 \mathrm{mmol} \times \mathrm{kg}$ cell water ${ }^{-1}$ $\times 15 \mathrm{~min}^{-1}$ and $K_{m}$ of 0.03 and $0.05 \mathrm{mM}$, respectively. The $V_{\max }$ of the large capacity, low affinity system in the patients was only $1 / 7$ of that in the control subjects, showing clearly impaired diamino acid uptake by the liver cells in LPI.

\section{Speculation}

In LPI diamino acids show depressed plasma concentrations, probably because of their impaired intestinal absorption and increased renal loss. If my findings on the kinetically abnormal diamino acid transport in liver slices of the patients are valid in vivo, the intestinal, renal, and hepatic defects must result in ornithine deficiency in the liver cells. As ornithine is the molecule on which urea is formed in the urea cycle, this deficiency will incapacitate the urea cycle and result in hyperammonemia. This mechanism is consistent with the basic chemical characteristics of LPI, the hyperdibasic aminoaciduria, and hyperammonemia after amino nitrogen loading. The defect of hepatic diamino acid transport is suggested to distinguish LPI from other diseases with low plasma diamino acid concentrations, the classic cystinuria, and the nonhyperammonemic hyperdibasic aminoacidurias.

Lysinuric protein intolerance $(11,12,14,20,28)$, a disease with autosomal recessive transmission (17), is characterized by diami- noaciduria, especially lysinuria, and by a subnormal increase in plasma urea concentration with hyperammonemia after protein intake. The hyperammonemia can be prevented by supplementing protein food with extra ornithine or arginine. The fasting plasma concentrations of lysine, arginine, and ornithine are only $25-50 \%$ of the normal mean levels (27).

The symptoms and signs of LPI are failure to thrive, vomiting and diarrhea after weaning, marked stunting, osteoporosis, leukocytopenia and decreased platelet count, and enlarged liver and spleen. Four of the 20 Finnish patients are mentally retarded.

Normal activities on substrate excess have been demonstrated for glutaminase (25), carbamyl phosphate synthetase, and the urea cycle enzymes, ornithine transcarbamylase, argininosuccinate lyase, the arginine synthetase system and arginase in liver tissue of the patients $(10)$. The kinetics of the arginase reaction are also normal (10)

The low plasma concentrations of arginine and ornithine $(21,26$, 27 ), and the prevention of the hyperammonemia and normalization of urea production by supplementation with one of these amino acids suggest decreased availability of ornithine at the site of urea production in the liver cells. The decreased plasma concentrations of arginine and ornithine are not alone a sufficient explanation for such ornithine deficiency, because their ranges overlap with normal, and some cystinuric subjects have similarly decreased plasma diamino acid concentrations (5) but no hyperammonemia. Because the metabolic clearance rates of arginine and ornithine from plasma are delayed in LPI (26), a defect in the transport of these diamino acids into or within the liver cells has been suspected $(25,26)$.

The aim of this study was to demonstrate the existence of such a defect. The amounts of diamino acids taken up by granulocytes and liver slices of LPI patients were measured. ${ }^{14} \mathrm{C}$-Labeled lysine, arginine, and ornithine were used for the granulocyte assays. For uptake by the liver slices the substrate was a nonmetabolized ${ }^{14} \mathrm{C}$-labeled diamino acid analogue, $l$-homoarginine. In the granulocyte assay one transport system was apparent; it was common to the three diamino acids and similar in patients and control subjects. In the liver assay evidence was obtained for the presence of at least two transport systems. The uptake kinetics of the patients' liver slices was grossly defective. This defect of diamino acid transport in the liver cells is believed to be the proximal factor responsible for the incapacitation of the urea cycle in LPI.

\section{MATERIALS AND METHODS}

\section{SUBJECTS STUDIED}

Granulocytes were isolated from blood of 11 patients with LPI. The clinical and biochemical features have been reported earlier (patients 1, 2, 6, 7, 9,10,14-16,18, and 19) (28). The ages of the 
patients ranged from 2-21 years; two were male. The control blood donors were 16 healthy members of the laboratory personnel and a hyperornithinemic subject (29). Their ages ranged from 8-45 years; seven were male. No association appeared between the age or sex of the subjects and the transport constants observed. The hyperornithinemic subject had transport constants well within the range of values of the healthy control subjects and was included in the control series.

Liver was obtained at laparotomy from five control subjects and three patients (patient 6,16 years; patient 7,21 years, and patient 9,6 years) $(12,28)$. The control subjects underwent operations for ventricular carcinoma (age 22 years), pyloric stenosis (54 years), duodenal ulcer (59 years), Meckel's diverticulum (42 years), and hamartoma of the liver ( 3 weeks). The uptake kinetic data for homoarginine were studied in three of the control subjects and two of the LPI patients.

\section{MATERIALS}

L-Lysine- $\left[U-{ }^{14} \mathrm{C}\right] \mathrm{HCl}$ (specific activity (sp act) $312 \mathrm{mCi} / \mathrm{mmol}$ ), $l$-ornithine- $\left[1-{ }^{14} \mathrm{C}\right] \mathrm{HCl}$ (sp act $\left.11.4 \mathrm{mCi} / \mathrm{mmol}\right), l$-arginine- $[U$ $\left.{ }^{14} \mathrm{C}\right] \mathrm{HCl}$ (sp act $336 \mathrm{mCi} / \mathrm{mmol}$ ), and inulin- $\left[{ }^{14} \mathrm{C}\right]$ carboxylic acid (sp act $6.1 \mathrm{mCi} / \mathrm{mmol}$, mol wt $5179 \pm 95$ ) were purchased from the Radiochemical Centre (33), and the corresponding nonlabeled compounds from Fluka AG (34). L-Homoarginine- $\left[{ }^{14} \mathrm{C}\right]$ guanido (sp act $50 \mathrm{mCi} / \mathrm{mmol}$ ), manufactured by Calatomics (35), was kindly donated by Dr. Halvor N. Christensen of the University of Michigan.

\section{GRANULOCYTE ASSAY}

Granulocytes were isolated from $50 \mathrm{ml}$ heparinized blood as described earlier (23). Clumping of the leukocytes was avoided by adding 20 units streptokinase and 5 units streptodornase $/ \mathrm{ml}$ cell suspension at each step of the isolation procedure after the primary dextran sedimentation. From $86-98 \%$ of the cells in the final preparation were granulocytes, and all but a few of them were alive, as shown by trypan blue covering. The cells were suspended in Tris-modified Krebs-Ringer bicarbonate buffer (23), pH 7.4, and preincubated in the buffer at $37^{\circ}$ for $5 \mathrm{~min}$ in a $95 \% \mathrm{O}_{2}-5 \% \mathrm{CO}_{2}$ atmosphere. The amino acid was added with the tracer and incubation was continued for 5-25 min. Samples of the suspension $(1.00 \mathrm{ml})$ were transferred to tubes precooled in an ice bath, and centrifuged immediately at $4^{\circ}$. A sample of the supernatant was diluted with water to $1: 50$, and $0.600 \mathrm{ml}$ was taken for measurement of radioactivity. The cell pellet was dried with strips of blotting paper, weighed, and washed twice with ice-cold $5 \%$ glucose solution. The final wet weight of the samples was between 0.95 and $14.08 \mathrm{mg}$. The cells were suspended in 1.00 $\mathrm{ml}$ of distilled water, boiled for $6 \mathrm{~min}$, and broken up by forcing three times out from a syringe through a No. 25 gauge needle. After centrifugation, $0.600 \mathrm{ml}$ supernatant was used for measurement of radioactivity. All determinations were made in duplicate. In separate experiments, the total water and extracellular water of the packed cells were measured by drying in an oven at $100^{\circ}$ for 24 $\mathrm{hr}$, and by incubating the cells with inulin- $\left[{ }^{14} \mathrm{C}\right]$ carboxylic acid for 30 min, respectively. The percentages obtained (mean $\pm 1 \mathrm{SD}$ ) were $93.1 \pm 1.9(n=21)$ for total water and $47.0 \pm 10.9(n=18)$ for extracellular water. These mean percentages are 10.2 and 11.1 percentage units higher than the values reported previously for packed leukocytes (23). This discrepancy may be caused by the difference in centrifugation technique: however, the effect of this discrepancy on the final results was negligible. The time course of uptake was studied in $0.05 \mathrm{mM}$ and the uptake kinetics in $0.025-$ $4.0 \mathrm{mM}$ diamino acid concentrations.

\section{LIVER ASSAY}

The liver specimens were placed immediately in ice-cold oxygenated Krebs-Ringer bicarbonate buffer, $\mathrm{pH} 7.4$, and cut with a Stadie-Riggs microtome (30) into $0.4-\mathrm{mm}$ slices within $15 \mathrm{~min}$ of the biopsy. The weight of the slices was assessed visually, and 1-4 slices, according to weight, were placed in 2-6 mi buffer in $25-\mathrm{ml}$ bottles. All incubations were made in duplicate. The slices were preincubated for $6 \mathrm{~min}$ before addition of $l$-homoarginine and tracer. Incubation proceeded under a continuous flow of moistened $95 \% \quad \mathrm{O}_{2}-5 \% \quad \mathrm{CO}_{2}$. After incubation the individual slices were dipped twice for 1 sec into cold $0.9 \% \mathrm{NaCl}$ solution, blotted with filter paper on both sides, and placed in weighed tubes containing $1.00 \mathrm{ml}$ of $\mathrm{H}_{2} \mathrm{O}$; the weight of each tube was recorded again. The wet weight of the slices from each bottle varied from $3.40-58.74$ $\mathrm{mg}$; usually it was $10-40 \mathrm{mg}$. All radioactivity was discharged from the cells by placing the tubes in a boiling water bath for 6 min. Radioactivity was measured in $0.900 \mathrm{ml}$ samples of the supernatants in these tubes after centrifugation and in the incubation medium (diluted 1:100 with water). Total water and extracellular water in the slices were measured separately from specimens of two control subjects and two patients, as described above for leukocytes. The means $( \pm 1 \mathrm{SD})$ for all subjects were $84.6( \pm 2.4 \%)$ $(\mathrm{n}=40)$ of the wet weight for total water and $30.1( \pm 2.4 \%)(\mathrm{n}=$ 10) for extracellular water. These proportions were comparable in patients and control subjects.

In these experiments l-homoarginine was used at the same concentrations as the other diamino acids in the granulocyte assays.

Part of each liver specimen was studied separately by light microscopy, and those of the patients also by electron microscopy. One control subject showed signs of cholestasis, but no liver cell destruction; in the others liver morphology was normal. In the patients, changes were seen in light microscopy in two and in electron microscopy in all three specimens (28). In the two older patients, clearly limited areas were present in the periportal or central parts of the liver lobules, in which the hepatocytes had ample pale cytoplasm and small pyknotic nuclei. In one patient (patient 6) such areas comprised about $20-30 \%$ of the total, but in the other only $5 \%$. In electron microscopy, the smooth endoplasmic reticulum was seen to be increased and its cisternae to be dilated. Some cells contained vesicles filled with fibrillogranular material, possibly formed by coalescence of the dilated cisternae of the smooth endoplasmic reticulum. In spite of these morphologic differences, consistent results were obtained from the individual patients in the incubation experiments.

\section{MEASUREMENT OF RADIOACTIVITY AND CALCULATIONS}

The radioactivity of the samples was measured with a Wallac Decem NTL ${ }^{314}$ liquid scintillation counter, with 2,5-diphenyloxazole (PPO)-1,4-bis[2-(5-phenyloxazolyl)]benzene (POPOP)-dioxane scintillation liquid (7.0 g PPO, $0.6 \mathrm{~g}$ POPOP, $80 \mathrm{~g}$ naphthalene in $1,000 \mathrm{ml}$ dioxane). As a rule, 10,000 counts were recorded.

The isotope distribution ratio, the ratio of counts per minute and milliliters of intracellular water to the counts per minute and milliliters of medium, was used as a measure of intracellu!ar amino acid accumulation and was calculated from the expression: $C_{i}=$ $\left[R_{t}-\left(C_{m} \times W_{e}\right)\right] /\left[W_{t}-W_{w}\right](23)$, where $C_{i}$ is the labeled amino acid concentration per milliliter of intracellular water, $R_{t}$ the net radioactivity of the cell pellet, $C_{m}$ the labeled amino acid concentration per milliliter of incubation medium, $W_{e}$ the inulin$\left[{ }^{14} \mathrm{C}\right]$ carboxylic acid space of the cell pellet, and $\mathrm{W}_{\mathrm{t}}$ the total water volume of the cell pellet. The velocity of amino acid uptake was calculated from the formula of Akedo and Christensen (1) by subtracting passive diffusion from total uptake: $\mathrm{dA}_{c} / \mathrm{dt}=\mathrm{Y}+$ $K_{D}\left(A_{f}-A_{c}\right)$, where $A_{c}$ is the intracellular substrate concentration, $Y$ the uptake velocity due to the saturable mechanism, $K_{D}$ the diffusion constant, and $A_{f}$ the extracellular substrate concentration. The diffusion constant $\mathrm{K}_{\mathrm{D}}$ was determined by extrapolation of the observed distribution ratios from $1.0-4.0 \mathrm{mM}$ substrate concentration to infinity, as has been described before (23). The results are presented in the ways described by Lineweaver-Burk and Hofstee-Augustinsson plots. Statistical calculations were performed with a Hewlett-Packard $9100 \mathrm{~B}$ calculator and standard programs (Student's $t$-test and linear regression analysis). 


\section{RESULTS}

\section{GRANULOCYTE ASSAY}

Lysine, arginine, and ornithine were transported into the granulocytes of both control subjects and LPI patients against a concentration gradient. The time courses of uptake and the final isotope distribution ratios are given in Table 1 . They were similar in the two groups of subjects.

The Lineweaver-Burk plot of the initial velocity of uptake of each amino acid gave a straight line (Fig. 1). The calculated maximal velocities $\left(\mathrm{V}_{\max }\right)$ of lysine, arginine, and ornithine uptake were similar, but the affinity constants $\left(\mathrm{K}_{\mathrm{m}}\right)$ differed (Table 2). Thus, in these experiments transport may have been mediated by a single system with different affinities for the three substrates. The kinetic constants of the control subjects and patients were similar,

Table 1. Isotope distribution ratios of diamino acids (concentration in intracellular water to concentration in incubation medium) in granulocytes of lysinuric protein intolerance patients and of control subjects in $0.05 \mathrm{mM}$ substrate concentration ${ }^{1}$

Incubation time
$\min$
Patients
Controls

\begin{tabular}{|c|c|c|}
\hline \multicolumn{3}{|l|}{ Lysine } \\
\hline 2 & & $1.6(2)$ \\
\hline 6 & & $2.3(2)$ \\
\hline 10 & & $3.2(2)$ \\
\hline 15 & & $3.3(2)$ \\
\hline 25 & $6.5 \pm 1.3(6)$ & $5.2 \pm 1.4(7)$ \\
\hline \multicolumn{3}{|c|}{ Arginine } \\
\hline 2 & & $1.9(3)$ \\
\hline 6 & & $3.4(2)^{2}$ \\
\hline 10 & & $4.0(2)$ \\
\hline 15 & & $5.3(2)$ \\
\hline 25 & $6.9 \pm 2.5(10)$ & $6.6 \pm 1.6(8)$ \\
\hline \multicolumn{3}{|c|}{ Ornithine } \\
\hline 2 & & $1.5(2)$ \\
\hline 6 & & $2.4(2)$ \\
\hline 10 & & $3.1(2)$ \\
\hline 15 & & $3.9(2)$ \\
\hline 25 & $5.2 \pm 2.3(8)$ & $5.2 \pm 1.4(5)$ \\
\hline
\end{tabular}

${ }^{1}$ The number of subjects studied is given in parentheses. Figures are means, and mean $\pm 1 \mathrm{SD}$ for 25 -min incubation. Not enough cells were obtained from the patients for complete studies.

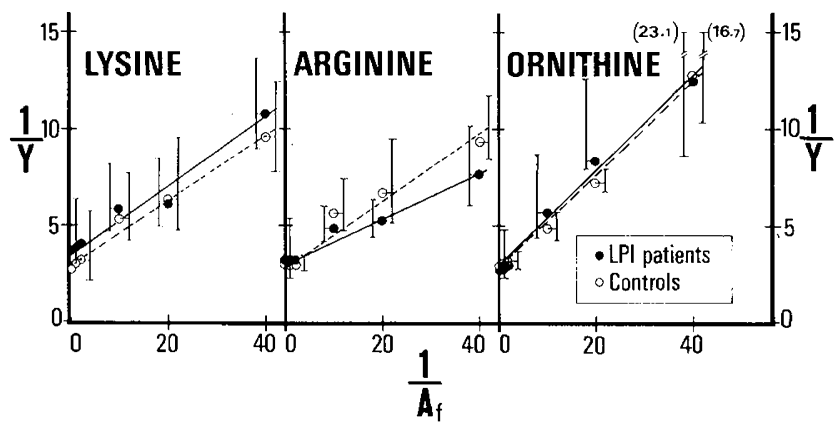

Fig. 1. Lineweaver-Burk double reciprocal plot of uptake velocity $Y$ (millimoles $\times$ kilogram of cell water ${ }^{-1} \times 5 \mathrm{~min}^{-1}$ ) of the diamino acids in isolated granulocytes of lysinuric protein intolerance patients and control subjects as a function of substrate concentration $\mathrm{A}_{\mathrm{f}}$ (millimolar concentration). The means $\pm 1 \mathrm{SD}$ of the observed isotope distribution ratios were calculated for each substrate concentration used; the plots and vertical lines indicate uptake velocities calculated from the mean \pm 1 SD isotope distribution ratios. The means were used for measurement of the kinetic constants (I, Table 2). The number of subjects studied is given in Table 2. except that the mean $V_{\max }$ for lysine was $9 \%$ smaller and for arginine $16 \%$ larger in the patients than in the control subjects. These deviations are believed to be insignificant.

\section{LIVER ASSAY}

Lysine, arginine, and ornithine are metabolized extremêly quickly in the liver and are not suitable for studies of transport in that the tissue. I therefore used $l$-homoarginine, which is carried by the same cellular transport systems as the natural diamino acids but is not metabolized (3). In preliminary studies with rat liver slices, homoarginine was concentrated into intracellular water up to distribution ratios of 2.5 in $0.05 \mathrm{mM}$ and of 4.2 in $0.025 \mathrm{mM}$ substrate concentration of the medium in $30 \mathrm{~min}$.

The time course of homoarginine uptake at $0.05 \mathrm{mM}$ concentration in the medium was similar in the liver slices of five control subjects and three patients (Table 3 ). The highest mean distribution ratio of homoarginine measured was 3.0 for the patients and 2.6 for the control subjects.

The initial velocity of homoarginine transport was measured in 15-min incubation experiments. After correction for passive diffusion, the Hofstee-Augustinsson plot suggested the existence of at least two transport systems for homoarginine in slices from both

Table 2. Affinity and capacity constants for transport of diamino acids into granulocytes of lysinuric protein intolerance patients and control subjects ${ }^{1}$

\begin{tabular}{|c|c|c|c|c|}
\hline & \multicolumn{2}{|c|}{ I } & \multicolumn{2}{|c|}{ II } \\
\hline & $\begin{array}{c}\mathrm{V}_{\max }, \\
\mathrm{mmol} \times \mathrm{kg} \\
\text { cell water } \\
\times 5 \mathrm{~min}^{-1}\end{array}$ & $\mathrm{~K}_{\mathrm{m}}, \mathrm{mM}$ & $\begin{array}{c}\mathrm{V}_{\max }, \\
\mathrm{mmol} \times \mathrm{kg} \\
\text { cell water } \\
\times 5 \mathrm{~min}^{-1}\end{array}$ & $\mathrm{k}_{\mathrm{m}}, \mathrm{mM}$ \\
\hline \multicolumn{5}{|l|}{ Lysine } \\
\hline Patients (7) & 0.29 & 0.05 & $0.30 \pm 0.12$ & $0.06 \pm 0.03$ \\
\hline Controls (5) & 0.34 & 0.06 & $0.33 \pm 0.14$ & $0.06 \pm 0.02$ \\
\hline \multicolumn{5}{|l|}{ Arginine } \\
\hline Patients (9) & 0.34 & 0.04 & $0.38 \pm 0.07$ & $0.05 \pm 0.02$ \\
\hline Controls (6) & 0.36 & 0.06 & $0.32 \pm 0.09$ & $0.06 \pm 0.02$ \\
\hline \multicolumn{5}{|l|}{ Ornithine } \\
\hline Patients (8) & 0.34 & 0.08 & $0.35 \pm 0.10$ & $0.10 \pm 0.05$ \\
\hline Controls (5) & 0.35 & 0.08 & $0.34 \pm 0.06$ & $0.09 \pm 0.04$ \\
\hline
\end{tabular}

${ }^{1}$ A single transport system was assumed to operate for each amino acid. The constants given under I were calculated from the mean values presented in Figure 1 (for details, see legend to Fig. 1). Those below II were calculated from individual curves and represent the mean $\pm 1 \mathrm{SD}$ values. The number of subjects studied is given in parentheses.

Table 3. Isotope distribution ratios of homoarginine in liver slices of lysinuric protein intolerance patients and control subjects in $0.05 \mathrm{mM}^{\mathrm{m}}$ substrate concentration of the medium ${ }^{1}$

\begin{tabular}{|c|c|c|}
\hline $\begin{array}{l}\text { Incubation time, } \\
\min \end{array}$ & Patients & Controls \\
\hline 5 & 0.67 & $0.44 \pm 0.18(2)$ \\
\hline 10 & & $0.86(1)$ \\
\hline 15 & $0.95 \pm 0.15(3)$ & $1.13 \pm 0.22(4)$ \\
\hline 20 & & $1.43(1)$ \\
\hline 30 & $1.52 \pm 0.15(3)$ & $1.67 \pm 0.27(5)$ \\
\hline 60 & $1.97 \pm 0.15(3)$ & $1.94 \pm 0.20(5)$ \\
\hline 90 & $2.57 \pm 0.16(3)$ & $2.49 \pm 0.62(5)$ \\
\hline 120 & $2.46 \pm 0.09(2)$ & $2.55 \pm 1.13(2)$ \\
\hline 150 & $2.99 \pm 0.31(3)$ & $2.40 \pm 0.51(5)$ \\
\hline
\end{tabular}

${ }^{1}$ Figures are means $\pm 1 \mathrm{SD}$. Numbers of subjects studied are given in parentheses. 
control subjects and patients (Fig. 2), systems $A_{p}$ and $B_{p}$ for the patients, and $A_{c}$ and $B_{c}$ for the control subjects. The affinity and capacity constants calculated for these systems are presented in Table 4; the values have not been corrected for the influence of the other transport systems $(2,24)$. At very low substrate concentration the affinities for the substrate were extremely high. The corresponding transport system $\left(\mathrm{A}_{p}\right.$ and $\left.\mathrm{A}_{c}\right)$ may thus be characterized as a high affinity, small capacity system. It was similar in patients and control subjects. In contrast, the mean $V_{\max }$ of transport in the patients' slices in medium with high substrate concentration (system $B_{p}$ ) was only $1 / 7$ of that of the control subjects' $\left(B_{c}\right)$. It appears likely that system $B_{p}$ of the patients is a mutant of the normal system $B_{c}$ of the control subjects. Thus, the liver slices of the patients have a defect in the low affinity, large capacity transport system.

\section{DISCUSSION}

The diamino acid transport kinetic data observed in the present study with liver slices of LPI patients and control subjects were similar at low but different at high substrate concentrations. The technique is accurate enough at the high substrate levels to establish beyond doubt the existence of a transport defect at high concentrations in LPI. Although results of experiments with liver

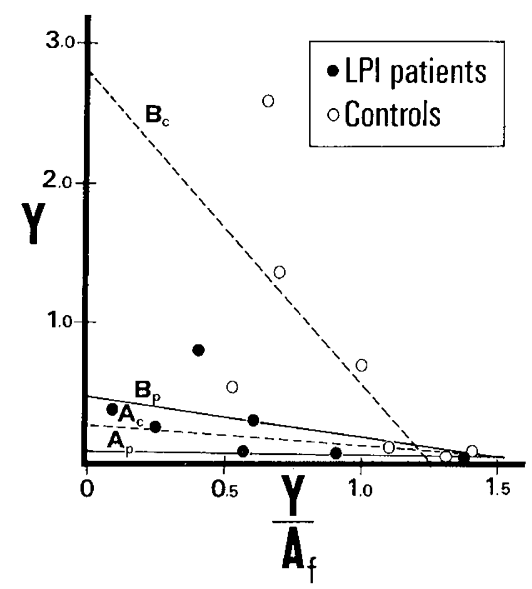

Fig. 2. Hofstee-Augustinsson plot of uptake velocity $Y$ (millimoles $X$ kilogram of cell water $\left.{ }^{-1} \times 15 \mathrm{~min}^{-1}\right)$ of $l$-homoarginine into liver slices of two lysinuric protein intolerance $(L P I)$ patients and three control subjects as a function of $\mathrm{Y} / \mathrm{A}_{\mathrm{f}}\left(1 \times \mathrm{kg}\right.$ cell water $\left.{ }^{-1} \times 15 \mathrm{~min}^{-1}\right)$, uptake velocity versus substrate concentration of the medium. slices can not be assumed to be directly applicable to the whole liver or organism, the present results probably indicate the defect responsible for the disease in the patients. The cells are able to take up diamino acids efficiently at extremely low substrate concentration, but with rising concentrations the uptake velocity does not increase normally. If the concentrations studied here are relevant in vivo, the liver in patients with LPI is unable to accumulate diamino acids adequately from plasma at the concentrations usually reached after meals. This would result in diamino acid deficiency in the liver cells.

In the renal tubuli of the patients the defect in reabsorption of diamino acids was largest at low or moderately increased filtered loads of diamino acids, and insignificant at high filtered loads (27). Two transport systems for diamino acids were suggested to be present in the tubuli, and the one which is predominant at lower filtered loads was concluded to be grossly defective in LPI. These findings are in apparent contrast to the present ones. It is possible, however, that an incorrect picture of the defect was obtained in the renal studies. Efflux of the diamino acids from the tubular cells may have diminished net absorption at low tubular loads, whereas, at high loads, passive influx probably formed a major part of the net absorption. Such factors may have masked the presence of the defect over the whole concentration range studied. Thus the defect in tubular reabsorption in LPI (27) may in fact be kinetically similar to that ouserved in the present study in the liver.

The metabolic clearance rates of arginine and ornithine from blood plasma have also been shown to be deficient in the patients (26). Reduced clearances were evident over the whole concentration range explored. The liver was suggested to be the site of the defect; this is confirmed by my present results.

Because the amounts of diamino acids transported into the liver cells in LPI do increase with substrate concentration, an enhanced supply of these acids ought to compensate for the defect. This has been studied by supplementation of protein food with extra arginine, which, in fact, prevents the hyperammonemia and permits normalization of the diet. In some of the patients a remarkable catch-up growth has occurred during years of therapy (28). The efficacy of the therapy is limited, however, by the poor intestinal absorption of arginine: too large a supplement produces osmotic diarrhea $(20,28)$.

The existence of two or more transport systems for diamino acids has been suggested previously by Rosenberg et al. (22), who presented evidence for two systems in human kidney cortex slices, and by Christensen et al. (4). who found three distinct systems in Ehrlich ascites tumor cells. Heterogeneity of transport like that evident for diamino acids in LPI has been demonstrated in many

Table 4. Approximated affinity and capacity constants for transport of l-homoarginine into liver slices of two lysinuric protein intolerance patients and three control subjects ${ }^{1}$

\begin{tabular}{|c|c|c|c|c|}
\hline & \multicolumn{4}{|c|}{ Concentration of medium } \\
\hline & \multicolumn{2}{|c|}{ Large } & \multicolumn{2}{|c|}{ Small } \\
\hline & $\begin{array}{c}\mathrm{V}_{\max } \\
\mathrm{mmol} \times \mathrm{kg} \text { cell } \\
\text { water }^{-1} \times 15 \mathrm{~min}^{-1}\end{array}$ & $\mathrm{~K}_{\mathrm{m}}, \mathrm{mM}$ & $\begin{array}{c}\mathrm{V}_{\max } \\
\text { mmol } \times \mathrm{kg} \text { cell } \\
\text { water }^{-1} \times 15 \mathrm{~min}^{-1}\end{array}$ & $\mathrm{~K}_{\mathrm{m}}, \mathrm{mM}$ \\
\hline Patients & 0.47 & 0.30 & 0.07 & 0.03 \\
\hline Controls & 2.78 & 2.24 & 0.27 & 0.14 \\
\hline \multicolumn{5}{|l|}{ II } \\
\hline Patients & $0.43(0.31-0.55)$ & $0.18(0.16-0.20)$ & $0.07(0.06-0.09)$ & $0.03(0.01-0.04)$ \\
\hline Controls & $3.08(1.18-4.22)$ & $2.49(0.75-3.76)$ & $0.14(0.09-0.18)$ & $0.05(0.02-0.08)$ \\
\hline
\end{tabular}

${ }^{1}$ Two transport systems were assumed to be in operation. The constants were directly calculated from the curves and were not corrected for the influence of the other transport system(s) $(2,24)$. The constants below I were obtained from the mean values presented in Figure 2 (for details, see legend to Fig. 2). Those below II are mean (range) values calculated from individual curves. 
cellular and organ preparations for several other amino acids or groups of amino acids $(2,18,24)$.

A defect in cellular transport of diamino acids is present in classic cystinuria $(6,16,31)$, in LPI (27), and in other types of hyperdibasic aminoaciduria $(13,19,32)$. In cystinuria, the defect has been demonstrated in kidney tubuli (6), and in the intestinal mucosa of some of the patients $(16,31)$, but not in granulocytes (23) or skin fibroblasts (8). A similar organ specificity of the defect seems to exist in LPI. Probably, the transport defect of classic cystinuria is different from that of LPI and is not present in the liver, as hyperammonemia is not a feature of cystinurics. There is some evidence for genetic heterogeneity among the hyperdibasic aminoacidurias $(13,19,28,32)$. LPI is suggested to be unique in having the defect expressed in the liver cells as well. Because the diamino acids provoke diarrhea in LPI patients $(20,28)$, it is likely that suitable techniques will demonstrate an intestinal absorption defect in LPI also.

A defect in the transport of diamino acids across the intracellular membranes might delay net uptake by the cells to the degree seen in LPI. An intracellular transport defect cannot be definitely excluded as the basic disorder in LPI, but is unlikely for two reasons. First, in LPI the transport defect involves all three diamino acids, whereas the only intracellular diamino acid transport system which has been demonstrated was specific for ornithine (7). Second, it seems unlikely that the intracellular membrane structures are directly involved in transepithelial transport in the kidney tubuli or in the cells of the intestinal mucosa. The many features common to the renal aminoacidurias also suggest that the defect is similarly located in them all. A defect in transport through the cell membrane adequately explains the findings in the diseases.

Presumably, the basic pathophysiology of LPI is as follows. Deficient absorption from the intestine and renal loss of lysine, arginine, and ornithine lead to decreased concentration of these amino acids in the plasma. The availability of these molecules to the liver cells is further impaired by the existence of the same transport defect in these cells. Thus, not enough ornithine is present in the liver cells for the production of urea by the enzymes of the urea cycle. This leads to accumulation of ammonia, aversion to protein-rich food, and a further decrease in liver ornithine concentration.

\section{SUMMARY}

Uptake of diamino acids by isolated granulocytes and by liver slices was studied in patients with LPI and in control subjects. ${ }^{14} \mathrm{C}$-Labeled lysine, arginine, and ornithine were used in the granulocyte assay and a nonmetabolizable diamino acid analog, $l$-homoarginine, in the liver assay.

Kinetic studies on diamino acid uptake by the granulocytes were consistent with the existence of one transport system common to the three diamino acids. The maximal velocity of uptake was approximately equal for the three amino acids and similar in patients and control subjects. In the liver slices, at least two transport systems became apparent as substrate concentration was varied from $4.0-0.025 \mathrm{mM}$. A low concentration system with high affinity and very small capacity for transport was similar in patients and control subjects. A high concentration system was also present in both groups, but in the patients had only $1 / 7$ of the maximal capacity observed in the control subjects. This defect grossly incapacitated the diamino acid uptake of the liver. In LPI, the observed defect, in conjunction with the deficient absorption in the kidneys and intestine, explains the lack of ornithine at the site of urea synthesis, which is evident from the impaired and ornithine-correctable urea production.

\section{REFERENCES AND NOTES}

1. Akedo, H., and Christensen, H. N.: Nature of insulin action on amino acid uptake by isolated diaphragm. J. Biol. Chem., 237: 118 (1962)
2. Christensen, H. N.: Methods for distinguishing amino acid transport systems of a given cell or tissue. Fed. Proc., 25: 850 (1966)

3. Christensen, H. N., Handlogten, M. E., and Thomas, E. L.: Na+facilitated reactions of neutral amino acids with a cationic amino acid transport system. Proc. Nat. Acad. Sci. U.S.A., 63: 948 (1969).

4. Christensen, H. N., and Liang, M.: Transport of diamino acids into the Ehrlich cell. J. Biol. Chem., 24l: 5542 (1966).

5. Crawhall, J. C., Scowen, E. F., Thompson, C. J., and Watts, R. W. E.: The renal clearance of amino acids in cystinuria. J. Clin. Invest., 46: 1162 (1967).

6. Fox, M., Thier, S., Rosenberg, L. E., Kiser, W., and Segal, S.: Evidence against a single renal transport defect in cystinuria. N. Engl. J. Med., 270: 556 (1964).

7. Gamble, J. G., and Lehninger, A. L.: Transport of ornithine and citrulline across the mitochondrial membrane. J. Biol. Chem., 248: 610 (1973).

8. Groth, U., and Rosenberg, L. E.: Transport of dibasic amino acids, cystine, and tryptophan in cultured human fibroblasts: Absence of a defect in cystinuria and Hartnup disease. J. Clin. Invest., 5I: 2130 (1972).

9. Kekomäki, M.: Intestinal ábsorption of $l$-arginine and $l$-lysine in familial protein intolerance. Ann. Paediat. Fenn., 14: 18 (1968).

10. Kekomäki, M., Räihä, N. C. R., and Perheentupa, J.: Enzymes of urea synthesis in familial protein intolerance with deficient transport of basic amino acids. Acta Paediat. Scand., 56: 631 (1967).

11. Kekomäki, M., Toivakka, E., Häkkinen, V., and Salaspuro, M.: Familial protein intolerance with deficient transport of basic amino acids. Report on an adult patient with chronic hyperammonemia. Acta Med. Scand., 183: 357 (1968).

12. Kekomäki, M., Vìsakorpi, J. K., Perheentupa, J., and Saxén, L.: Familial protein intolerance with deficient transport of basic amino acids. An analysis of 10 patients. Acta Paediat. Scand., 56: 617 (1967)

13. Kihara, H., Valente, M., Porter, M. T., and Fluharty, A. L.: Hyperdibasicaminoaciduria in a mentally retarded homozygote with a peculiar response to phenothiazines. Pediatrics, 51: 223 (1973).

14. Malmquist, J., Jagenburg, R., and Lindstedt, G.: Familial protein intolerance: Possible nature of enzyme defect. N. Engl. J. Med., 284: 997 (1971).

15. Malmquist, J., and Hetter, B.: Leucocyte glutaminase in familial protein intolerance. Lancet, ii: 129 (1970).

16. McCarthy, C. F., Borland, J L., Jr. Lynch, J. J., Jr, Owen, E. E. and Tyor, M. P.: Defective uptake of basic amino acids and $\mathrm{L}$-cystine by intestinal mucosa of patients with cystinuria. J. Clin. Invest., 43: 1518 (1964).

17. Norio, R., Perheentupa, J., Kekomäki, M., and Visakorpi, J. K.: Lysinuric protein intolerance, an autosomal recessive disease. A genetic study of 10 Finnish families. Clin. Genet., 2: 214 (1971).

18. Oxender, D. L.: Membrane transport. Ann. Rev. Biochem., 41: 777 (1972).

19. Oyanagi, K., Miura, R., and Yamanouchi, T.: Congenital lysinuria: a new inherited transport disorder of dibasic amino acids. J. Pediat., 77: 259 (1970).

20. Perheentupa, J., and Visakorpi, J. K.: Protein intolerance with deficient transport of basic amino acids. Another inborn error of metabolism. Lancet, ii: 813 (1965).

21. Perheentupa, J., Kekomäki, M., and Visakorpi, J. K.: Studies on aminonitrogen metabolism in familial protein intolerance. Pediat. Res., 4: 209 (1970).

22. Rosenberg, L. E., Albrecht, L., and Segal, S.: Lysine transport in human kidney: Evidence for two systems. Science, 155: 1426 (1967).

23. Rosenberg, L. E., and Downing, S.: Transport of neutral and dibasic amino acids by human leukocytes: Absence of defect in cystinuria. J. Clin. Invest., 44: 1382 (1965)

24. Scriver, C. R., and Mohyuddin, F.: Amino acid transport in kidney. Heterogeneity of $\alpha$-aminoisobutyric uptake. J. Biol. Chem., 243: 3207 (1968).

25. Simell, O., Perheentupa, J., and Visakorpi, J. K.: Leukocyte and liver glutaminase in lysinuric protein intolerance. Pediat. Res., 6: 797 (1972).

26. Simell, O., and Perheentupa, $\mathbf{J}$.: Defective metabolic clearance of plasma arginine and ornithine in lysinuric protein intolerance. Metabolism, 23: 691 (1974).

27. Simell, O., and Perheentupa, J.: Renal handling of diamino acids in lysinuric protein intolerance. J. Clin. Invest., 54: 9 (1974)

28. Simell, O., Perheentupa, J., Rapola, J., Visakorpi, J. K., and Eskelin, L.-E.: Lysinuric protein intolerance. Amer. J. Med., in press.

29. Simell, O., and Takki, K.: Raised plasma-ornithine and gyrate atrophy of the choroid and retina. Lancet, $i: 1031$ (1973).

30. Stadie, W. C., and Riggs, B. C. C.: Microtome for the preparation of tissue slices for metabolic studies of surviving tissues in vitro. J. Biol. Chem., 154: 687 (1944)

31. Thier, S., Fox, M., Segal, S., and Rosenberg, L. E.: Cystinuria: In vitro demonstration of an intestinal transport defect. Science, 143: 482 (1964).

32. Whelan, D. T., and Scriver, C. R.: Hyperdibasicaminoaciduria: An inherited disorder of amino acid transport. Pediat. Res., 2: 525 (1968).

33. Amersham, England.

34. Buchs, Switzerland

35. La Jolla, Calif.

36. All procedures have been performed in accordance with the provisions set forth in the Declaration of Helsinki. Informed consent was obtained from all subjects studied and from their guardians.

37. Martti Kekomäki, M.D., performed the liver biopsies on the LPI patients. His work is gratefully acknowledged. The skillful technical assistance of Mrs. Arja Johansson., B.Sc., is appreciated.

38. This study was supported by the Finnish Medical Foundation, the Sigrid Jusélius Foundation, Finland, and the Foundation for Pediatric Research, Finland.

39. Requests for reprints should be addressed to: O. Simell, M.D., Helsinki University Children's Hospital, SF-00290 Helsinki 29, Finland.

40. Accepted for publication January 10, 1975 